\title{
Logico-Semantic ReLations in BataK Toba Wedding CERemony
}

\author{
Triana Manalu ${ }^{1}$, Meisuri $^{2}$, Widya ANDAYANi $^{3}$ \\ ${ }^{123}$ UNIVERSITAS NEGERI MEDAN
}

\begin{abstract}
The research focused on logico-semantic relations in the Batak Toba wedding ceremony. The research aimed to discover the types of logico-semantic relations used in mangulosi and describe how they were realized in the Batak Toba wedding ceremony. The research was conducted by using the descriptive qualitative method. The data were taken from 2 wedding ceremony videos from 104 clause complexes selected. The study's finding showed that there were 9 of the logico-semantic relations types used in the Batak Toba wedding ceremony. They were consecutively hypotactic enhancement, hypotactic elaboration, paratactic enhancement, paratactic elaboration, hypotactic locution, paratactic extension, hypotactic extension, hypotactic idea, and paratactic idea. The logico-semantic relations were realized in mangulosi in Batak Toba wedding ceremony consecutively conjunction, verb, preposition, prepositional phrase, and adverbial clause which the utterances aimed about the message, prediction in the future, advice, hope, and blessing of hulahula for the bridegroom.
\end{abstract}

Keywords: hula-hula's utterances, mangulosi, Batak Toba wedding ceremony, logicosemantic relations, realization. 


\section{INTRODUCTION}

As a social creature, human needs to interact each other. Language is the primary vehicle which ideas or experience is shared and transmitted. Therefore, language plays an essential role in all societies, namely communication to transfer information through language. Communication can be connected when the speaker and the listener get the meaning of the utterances. Halliday (2014:30) states that experiential meaning is used to describe ideas, and logic is concerned with the relationship between or among classes that will lead to cohesion. Meanwhile, the interdependency between the clauses should be related.

Nowadays, a wedding ceremony in Batak Toba is a common thing and found in many places in Indonesia, where the Bataknese is spread, including in urban areas and rural areas. Hence, the ethnic wedding ceremony of Batak Toba between the urban area and rural area in this era has been different because it is affected by three main factors: education, overseas, and globalization. The three factors caused the wedding to be simplified (Pasaribu, Sukirno, \& Sri, 2017). People who live in urban areas are less understanding of the procession than people in a rural area of the Batak Toba wedding ceremony especially understanding the oral tradition in the wedding ceremony. Therefore, giving a blessing and hope that is delivered orally is often simplified.

However, several previous studies on logico-semantic relation, Siahaan \& Napitupulu (2014), Ginting (2014), and Purba (2018), studied the logical function in traditional ceremonies. They found that the logico-semantic relation exists in Batak Toba speeches which the ceremony was purposed to give bless and hope for the shoulders in the ceremony.

The choice of logical meaning is meant to analyze the text to comprehend the relation of one clause to another clause. Thus is interesting to analyze the speeches in the wedding ceremony of Batak Toba using the logical meaning to find out how the reader can obtain the relation of the clauses and the meaning of the logico-semantic relation in the hula-hula's utterances $(\mathrm{H})$. In another way, to obtain better meaning even to avoid misunderstanding to predict the speaker's utterances

\section{REVIEW OF LITERATURE}

\section{Logico-Semantic Relations}

Logico-semantic relations is the relation which indicates the meaning in clauses combined in clause complex. It refers to the meaning between paratactic taxis and hypotactic taxis which are about the relation in the clauses that also have connection with the using of conjunction, adverb, and so on.

a. Taxis

Halliday (2004 : 373) states that taxis is known technically as degred 4 s 
degree of indenpendency. It is divided into two, parataxis and hypotaxis. Those are two basic forms taken by logical relations in natural language. Parataxis is equal element where the hypotaxis is vice viersa (unequal element). One clause complex consists of two interdependent clauses which may be either parataxis or hypotaxis. Both of the taxis' types can be combined in a clause complex, each of th clauses consists of parataxis and hypotaxis and they bind relationships between equal and unequal status.

b. Parataxis

Parataxis is an independent clause in which each of clause in a complex clause consists of a complete sentence that can stand individually. The fistt clause function o initiating and the scong is continuing sunction. The status of each clauses has the same status (equal). And symbolized by $1,2,3, \ldots$ (depends on the sentences) For example, my wife is a housewife while I am a worker. The example shows that the first clause my wife is a housewife symbolized by 1 and the second clause "while i am a worker" symbolized by 2 , both of the clauses can stand alone and they are equal status.

\section{c. Hypotaxis}

Hypotaxis is inverse of parataxis, it is one clause that can not stand by itself but the other has to be dependent on the other clause that is dominant and the other is independent. The clause is unequal status which the following clause is different on the modifying. Hypotaxis is symbolized by Greek Letters $a, \beta, \gamma$, etc. For example, my father told me that he is building a new house for us. The clauses show that the first clause is dominant which has the relation to the following status, the clause can stand alone. While the second clause is connected with the first which is dependent but relates with the previous clause.

\section{Logical Relation}

Logical semantic is defined as the meaning existed in parataxis and hypotaxis relations, which clause is representing ideas. It is the relation which indicates the meaning formed when a clause is combined with another in a clause complex. Halliday and Mattiessen (2004: 376) say that there is a wide range of different logico-semantic relations any of which may hold between a primary and a secondary member of clause complex, it was revised that it is possible to group into smaller types, they are expansion and projection.

a. Expansion

Expansion relates two the phenomenon as being of the same order experience. It relates processes by arranging additional information. The additional information is distributed through secondary clauses. It invallzs 
three types of relationship: elaboration, extention, and enhancement. This relationship is cross-classified with the system of interdependence or taxis.

b. Elaboration

Elaboration marked by $(=)$ which divided into two, the first is paratactic elaboration (1=2) which Halliday (2014:462) states that the combination with parataxis divided into the first and two of which could be regarded as apposition between clauses. The second is hypotactic elaboration $(\alpha=\beta)$ is the combination of the elaboration with hypotactic gives the category off nondefining relatives clause (non-restrictive, descriptive). It is a strategy to give the background information (Halliday, 2014 : 464). It devided into 4 types, they are specification, exemplification, restatement, and comment. For example, Cinny finds many useless things while cleaning the house, like trash, elementary uniform.

c. Extension

Extension is purposed to extends the meaning of the clause by adding something new, usually involving by conjungtion "and" and "or". For example, I play a drum and my friend plays piano. It is marked with $(+)$. Halliday (2014: 471) states that extension is consist of paratactic and hypotactic which can be operated although there are certain gaps in paradigm. It marked $(1+2)$. And the other, hypotactic extension $(\alpha+\beta)$. One clause expands addition (adding new element), variation (giving exception) and alternation (offering an alternative).

d. Enhancement

Enhancement involves circumtancial relationship where the circumtancial information is coded a new clause rather than within the clause. It deals with cutting off the clause or heightening, marked with (x). Halliday (2014 : 476) states that enhancement one clause (sub complex) enhances the meaning of another by qualifying it. Paratactic enhancement is the circumstantial feature which a kind off co-ordination, while the hypotactic enhancement $(\alpha \times \beta)$ is commonly used. There are 6 types of enhancement. They are, temporal, cause or conditional, spatial, and manner. For ex, Faldi is being a success person in life by working hard.

\section{Projection}

Projection consists of two parts, the projecting (clause) "They said" and the projected (clause) "We'll stay up together". Said is the projecting process. Projecting process projections divided into locution and idea. Locution is a projection with verbal process , Halliday (1994:252) says that it includes : 
2. Specific verb to: statements; tell receiver, remark, observe, point out, report,anounce,etc. Questions; ask, demand, inquire,quiry

3. Verbs 'say' is classified from the circumtancial elements using this word which has meaning of responce, explanation, reservation, continueing, intterupting, and warning

4. Verbs having connotations of kinds for instance insist, complain, cry, shout, boat,murmur, stammer.

In addition, Idea is projected by mental process which is used to project a linguistic experience such as think, imply, wonder, reflect, want, wish, etc.

\section{Realization of Logico-Semantic Relation}

a. Conjunction

Conjunction often functions the sentence, it improves meaning in a sentence complex through separate a clause with the other clauses. There are 3 types of conjunctions, are: subordinating conjunctions (after, because, and, if that, alhough, eventhough, till, before, unless, when, where, while), coordinating conjunctions (and, but, for, or, nor, also), and correlative conjunctions (either-or, neither-nor, both-and, not onlybut also, thought-yet) Wren and Martin (1978:206) For ex, Ike has left when Agatha arrives in the museum.

It can be found the conjunctions in Batak Toba language, they can be jala, alana, alai. For ex, mansai las do roha nami jala mansai sonang situtu roha mamereng angka na ribur di hutaon (we are very joyful and feel comfort to see the the ceremony in this village today).

b. Preposition

Preposition is a word or group of words which used with a noun, pronoun, or noun phrase to show direnction, location, timr, or introduce an object whose functions for connecting a noun or pronoun with a verb or adjective in a clause. It devided into two. The first is preposition of place (in, on, above, under, beneath, to, near, beyond etc), and the second is preposition of time (at, on,in, during, over, for since, by, between, etc).

a) Prepositional Phrase

It is a group of words including a preposition and a noun or its equivalent.

Foe ex, Septa goes to the party, in addition his homework has finished.

b) Verb

Verb is one of the part of speech which functions as modyfier the predicate or an action in a sentence or clause. Main component in a predicate is verb because there is no sentence if it does not combined with a verb, only a bunch of them with an incomplete thought. There are some types of verb, they can be regular verb (wash >washed > washed) and irregular verb (sing > sang>sung), non-finite verb phrase. For ex, Luita cleans the whiteboard. 


\section{c) Adverbial Clause}

The clause usually goes in front position in end position depends on the what is new or neccessary information in order clause. In addition, an adverbial clause is a part in the same way as other adverbials are, for instance an adverb or prepositional phrase. Itdevided into three. They are clause of time, clause of reason, and clause of purpose.

\section{Wedding Ceremony of Batak Toba}

The wedding ceremony is an oral tradition that this case will let the guest to give them prayer within their division. Dalihan Na Tolu is the philosophy of Batak Toba is the rule for celebrating any ceremony. It has 3 parts, somba marhula-hula, manat mardongan tubu, and elek marboru (Armawy,2008). Hula-hula is greeting to the parents and brothers from bride, Dongan Tubu are people who have the same surname with Suhut (groom's family), and Boru is the husband of the female side of Suhut-dongan tubu. Each part has its role to play in ceremony of Batak Toba.

As the explanation before, hula-hula as one of the important thing in Batak Toba takes its role in giving blessing and hope that Bataknese believes as worth it. Hula-hula in Batak Tobanese devided into 2 origins, they are from bride and groom side; the equal clan with bride, the equal can with bride's mother, equal clan with each bride's sister in law, the equal clan with groom's mother, the equal clan with groom's grandmother, and the equal clan with each groom's sister in law. Those kinds of family are named as shown below:
a. Hula-hula (Bride's family)
b. Tulang (Family of Groom family)
c. Bona Tulang (Family of groom's grandmother)
d. Tulang rorobot (family of bride's mother)
e. Bona ni Ari (Family of the uncle of Grand father's groom)
f. Hula-hula na marhaha anggi (The family of each bride's sisterinlaw)
g. Hula-hula anak manjae (The family of each groom's sisterinlaw)
h. Mangulosi

Mangulosi is the unique tradition in Batak Toba which using ulos, traditional Batak cloth worn covering shoulder that has been exist for along time. Mangulosi is the way people deliver the traditional sarong to cover the shoulder in the related ceremony. It is entangling the giver and receiver according to the contexts of ceremony, whether wedding ceremony or other ceremony tradition of Batak Toba which has different purpose. In weddinng ceremony, ulos is given hopefully to keep the new family warm (be blessed, be happy) and protects their family. 


\section{RESEARCH METHODOLOGY}

According to Sugiono (2016:9), stated that qualitative research method applied through the combination, data analysis in qualitative, and result of research more emphasize meaning than generalization. This study used qualitative descriptive method where the purpose is to find the logico-semantic relations in hula-hula's utterances $(\mathrm{H})$ of wedding ceremony of Batak Toba. The steps of collecting data were (1) Recording Batak Toba wedding ceremoy during mangulosi tradition; (2) Transcribing hula-hula's utterances; and (3) Interviewing 2 informants speaker od Batak Toba for more accurate information.

The data were analyzed by using descriptive qualitative method. The procedure of data collection were observation. They are, (1) Data reduction, such as identification the types of logico-semantic relations in Batak Toba wedding ceremony; (2) Data display; (3) Verification and conclusion.

The second procedure was the analysis with Miles and Huberman (1984) that the data from the interview section. It was analyzed through, (1) Transcribing the data from the videos; (2) Classify the data to each type of logico-semantic relations; (3) Interviewing the the informants to answer the realization of logico-semantic relations in hula-hula's utterances $(\mathrm{H})$ in Batak Toba wedding ceremony.

\section{FINDINGS and DISCUSSIONS}

\section{Findings}

All of the data analysis for all types of logico-semantic relations by hula-hula's utterances $(\mathrm{H})$, the findings were presented below:

1. Based on the Systemic Functional Linguistics (SFL) theory, the types of logicosemantic relations which were found in hula-hula's utterances $(\mathrm{H})$ were hypotactic enhancement, paratactic enhancement, hypotactic elaboration, paratactic elaboration, paratactic extension, hypotactic extension, hypotactic locution, paratactic idea, and hypotactic idea. Meanwhile, the paratactic locution were not exist in the utterances. From the nineth types, hypotactic enhancement appeared as the most dominant type in the data. It was indicated that hula-hula mostly used the spatial, manner, causal and conditional in their utterances while delivering the messages.

2. The five realization of logico-semantic relations were used in hula-hula's utterances which were verb, conjunction, adverbial clause, preposition, and prepositional phrase. Conjunction appeared as the most dominant type of realization in the data. It was followed by verb, preposition, prepositional phrase and adverbial clause. All of the types of realization were applied in hula-humpa 
utterances in magulosi in Batak Toba wedding ceremony.

\section{Discussions}

The findings showed that logico-semantic relation gave contributions to see what was going on the text based on the text context. It was appropriate with Halliday's theories about logico-semantic relations. From 104 data findings, there were 9 types found in the data, and paratactic locution was not appeared in the data. It was none in hula-hula's utterances that means that the quotes were only applied with independent clause where the hula-hula always delivered their word intermittently. The continued conversation delivered by hula-hula shown in using verb as the realization of the logico- semantic relations.

Compared with the previous study of Siahaan and Napitupulu (2014) who searched the logical meanings of the traditional wedding speeches of the Batak Toba speeches, they found 15 data and there were 142 utterances. All of the types in logico-semantic relations were exist in this study, while there was no realization discussed in the study. In their study, there was no peculiarity with the step of the wedding ceremony and there was no specific meaning of the utterances of the speaker. The meaning of the speaker utterances depended on the context of the study. In addition, the other previous researcher that learned about the same topic has some difference depended on the context situation. In this study was specificly for the hula-hula's utterances $(\mathrm{H})$ in mangulosi ceremony. It focused on the types and realization of logicosemantic relations in hula-hula's utterances which specificly in mangulosi tradition. The findings in this study were different with the previous study where not all of the types found inthe data while it also focused on the realization of those utterances.

From 10 types of logico-semantic relations in hula-hula's utterances $(\mathrm{H})$, there were 9 types applied in the utterances. hypotactic enhancement appeared as the dominant type in the utterances that occured with the relation of one clause to the other clause through the enhancement types. The realization also being indicated which the most appeared was conjunction and followed with verb. It was showed that the using of verb that separating by comma were mostly used and it was the way for the speaker to take a pause in speaking, while conjunction type used to highten the logical relation between one clause to other caluses.

Conjunction used can be asa (so that), alani or alana (because), jala (and), alai (but), songon (as), nang pe (eventhough) ima (where), and na (that/which/who). The using of adverbial clause can be molo (if) as the lowest one. The using of verb mostly separated the clause with comma and the other shown by the other verb, for instance mandongani (company) and the other verbs. It also found the using of preposition can be sian (from) and the lowest appeared was prepositional phrase was ditikkion (in this occasion). 
Related to Halliday's theory, the findings were appropriate to the types and the realization. it was also shown in Siahaan and Napitupulu (2014). The findings showed that logico-semantic relations used by hula-hula in Batak Toba ceremony were depended on their position and the content of the ceremony such the way hula-hula delivered their statement, blessing, hope, and prayer that were meaningful for the bridegroom. In some of the utterances said that they have authority in Batak Tobanese tradition to give blessing for the bridegroom.

While delivering information, the speaker concerned with language that they used. It had to be appropriate to convey the messages to the public, especially for bridegroom. In all of the hula-hula's utterances $(\mathrm{H})$ present their messages, prediction in the future, advice and hope and blessing for them through ulos that they delivered to the bridegroom. Factly, The ulos giving to the bridegroom were different, depended on the giver and their (hula-hula) position in the ceremony whether they are from the bride's family or groom's family.

The findings have beneficial when delivering idea. People need to know logical relations in relating one clause to another. Through understanding logical relations, speaker can rearrange the message that they want to deliver in order to make it more organized. In case the listeners need to understand the realization of logico-semantic relation to make them easily getting the message and information that the speaker delivered in wedding ceremony of Batak Toba traditions.

The utterances in the video mostly used Bataknese language. It shows that the tradition and people in both of the sources still maintain their language. However. This study is appropriate to attract the addressees or readers in formal or non-formal situation.

\section{CONCLUSIONS AND SUGGESTIONS}

\section{Conclusions}

After analyzing logico-semantic relation in hula-hula's utterances $(\mathrm{H})$, the findings and the discussion can be concluded as the following conclusion were drawn:

1. All of the types of logico-semantic relations were used in mangulosi Batak Toba wedding ceremony by hula-hula, they were alternately hypotactic enhancement (38.46\%), hypotactic elaboration (16.34\%), paratactic enhancement (13.46\%), paratactic elaboration (9.61\%), hypotactic locution (7.69\%), paratactic extension (6.73\%), hypotactic extension (3.84\%), hypotactic idea (2.88\%), paratactic idea $(0,96 \%)$. There is one type namely paratactic locution that was not found in the data.

2. The logico-semantic relations realized in hula-hula's utterances by 5 ways, they were alternately conjunction (49.03\%), verb (43.26\%), preposition (3.84\%), prepositional clause $(2.88 \%)$, and adverbial clause $(0.96 \%)$. The realization that used by hula-hula's utterances $(\mathrm{H})$ to make logical connection between the 
clauses while delivering their utterances. However the realization could determine the types of logico-semantic relations.

\section{Suggestion}

Based on the conclusions abobe, there are some important suggestions needed to be examined. First, it is suggested for young generations to know about logico-semantic relations in traditional Batak Toba wedding ceremony. Second, it is expeted to improve the knowledge in Bataknese language so that they can get the meaning from the speaker's utterances in Batak Toba wedding ceremony. Third, it is also suggested to do more research about the meaning speaker's utterances in Batak Toba wedding ceremony.

\section{REFERENCES}

Anggara. 2015. Tactic System and Logico-Semantic Relations of Clause Complexes in Asean Free Trade Area (AFTA) Agreement. Accesed on October, $9^{\text {th }} 2016$

Armawy, A. 2008. Kearifan Lokal Batak Toba Dalihan Na Tolu dan Good Governance dalam Birokrasi Publik. Jurnal Filsafat, XIX (2).

Butar butar, K. (2018). The Aesthetic Study of Traditional Cloth of North Sumatera.ICOBEST.

Eggins, S. (2005). An Introduction to Systematic Functional Lnguistics $\left(2^{\text {nd }} e d\right)$. Sydney.

Gerot.L and Wignell. 1994. Making Sense of Functional Grammar Sydney: Gerd Stabler. Ginting. 2014. The Logical Function in Simate-mate (The Mourning Tradition of Karonese's Culture). Accussed, in $20^{\text {th }} 2018$.

Halliday, M.,\& Matthiessen, C. 2004. An Introduction to Functional Grammar $\left(3^{\text {rd }} e d\right)$.London: Hodder Arnold

Halliday,M.,\& Matthiessen, C. 1994. An Introduction to Functional Grammar $\left(4^{r d} e d\right)$. UK-State University of Birmingham: Michael Toolan.

Isaac, P. N. 2017. The Elaborative Logico-Semantic Relation of Conjunctions in Ekegusii Texts. The Journal of Pan African Studies. XI(1). 
Kozok, U. 1999. Warisan leluhur sastra lama dan aksara Batak. Jakarta: Kepustakaan Populer Gramedia, École française d'Extrême-Orient.

Lubis, A. 2018. Logico Semantic Relation in Newspaper Texts on Jakarta Attack. Proceedings of the Sixth International Conference on English Language and Teaching(ICOELT -6)

Pagano., Paulo \& Ferreguetti. 2018. Verbal And Verbal-Visual LogicoSemantic Relations In Picturebooks: An English-Brazilian Portuguese Parallel Corpus Study.Esta obra tem licença Creative Commons.

Parry, Milman. 1971. The Making of Homeric Verse: The Collected Papers of Milman Parry. Oxford: Oxford UP.

Pasaribu, D, M., Sukirno, \& Sudaryatmi. 2017. Perkembangan Sistem Perkawinan Adat Batak Toba di Kota Medan. Diponegoro Law Journal.VI(2).

Purba. 2018. Logical Relation Anak Boru Sanina in Simalungun wedding ceremony. State University of Medan

Sugiyono. (2016). Metode penelitian: kualiatif, kuantitatif, dan $r \& d$. Bandung: alfabeta 
Saragih, Amrin. 2014. Discourse Analysis. Medan: Universitas Negeri Medan.

Siahaan, S., Napitupulu, S. \& Tampubolon. 2014. The Logical Meanings of the Traditional Wedding Speeches of the Batak Toba People. International Journal of Language and Linguistics,II(5)328-342.

Simamora and Sihaloho. 2016. Microfinance practice in Batakese traditional wedding party. International Conference of Integrated Microfinance Management.

Voorhoeve, P. 1955. Critical survey of studies on the languages of Sumatra.'s- Gravenhage: Nijhoff.

Yuniar. 2018. Logico-Semantic Relation of Clauses Used in Analytical Exposition Written by The Third Semester Students of English Department.Journal of Research on Applied Linguistics Language and Language Teaching, II(1)121-128. 